\title{
CORRELATION OF DENGUE VIRUS SEROTYPE AND DVI SEVERITY IN ADULT PATIENTS
}

\author{
Suci Andriani ${ }^{1,2}$, Aryati $^{2}$, Usman Hadi $^{3}$ \\ ${ }^{1}$ Dr. Ramelan, Hospital Surabaya, Indonesia. E-mail: drsucipk@gmail.com ${ }^{2}$ Department of Clinical Pathology, Faculty of \\ Medicine, Airlangga University/Dr. Soetomo Hospital, Surabaya, Indonesia ${ }^{3}$ Tropical-Infection Disease Unit, Department of \\ Internal Medicine, Airlangga University/Dr.Soetomo Hospital, Surabaya, Indonesia
}

\begin{abstract}
The clinical manifestation of dengue virus infection is often not clear, varies widely from mild to severe. Exposure of dengue virus which serotype is different from a previous infection is a risk factor for the severe manifestation of dengue virus infection. Dengue hemorrhagic fever is classified into four degrees of severity based on clinical manifestations and laboratory results. Real-time RT-PCR Dengue can detect dengue virus serotype in early dengue virus infection. The aimed of this study was to prove the correlation between dengue virus serotype and degree of severity in adult patients. This study was a cross-sectional observational design done in February until July 2016. Subjects consisted of 100 dengue virus infection patients. Serum of the patients was examined using Real-time RT-PCR Dengue (Simplexa ${ }^{\mathrm{TM}}$ Dengue). It was shown that from 46 patients with DENV-3 serotype was $63 \%$, DENV-2 serotype $17.4 \%$, DENV-1 serotypes $17.4 \%$ and mixed infection of DENV-1 and DENV-3 serotype $2.2 \%$. There was not any DENV-4 serotype. Dengue Hemorrhagic Fever (DHF) stage I was $47.8 \%$, DHF stage II was $30.4 \%$, DHF stage III was $10.9 \%$ and Dengue Fever was $10.9 \%$. There was not any DHF stage IV. There was not enough evidence that DENV-3 correlated with the degree of severity $(p=0.510)$. Based on this research, DENV-3 serotype was the dominant serotype prevalent at the Dr. Soetomo Hospital. There was no correlation between viral dengue serotype and severity in dengue adult patients in this study.
\end{abstract}

Keywords: Dengue, Real-time RT-PCR dengue virus, serotype, degree of severity

\section{INTRODUCTION}

In Indonesia, the prevalence of dengue hemorrhagic fever (DHF) in 2015, according to the Ministry of Health, was 1817 cases. In 2014, the prevalence of Dengue Hemorrhagic Fever (DHF) in the East Java Province even was considered as an extraordinary incidence due to an increase in its prevelence as much as $980(46 \%){ }^{1}$

Dengue virus is a genus of flavivirus of the flaviviridae family spread by Aedes aegypti and Aedes albopictus mosquitoes transmitted through vectors. Clinical manifestations of Dengue Virus Infection (DVI) associated with its severity degrees are often known to be not typical, varying from asymptomatic to symptomatic ones. ${ }^{2}$ The symptomatic manifestations of Dengue Virus Infection (DVI) consist of undifferentiated fever, Dengue Fever (DF), Dengue Hemorrhagic Fever (DHF), Dengue Shock Syndrome (DSS),
Expanded dengue syndrome and various organ abnormalities. Further complications of DVI even can lead to death. $^{2}$

Therefore, clinical and laboratory manifestations, according to the WHO in 2011, must be examined to determine and establish the diagnosis of dengue virus infection. ${ }^{2}$ Patients who have been exposed to different dengue virus serotypes will have risk factors for severe DVI manifestations or DSS., Serological test is usually performed to detect antigens in the form of NSI3, while anti-dengue IgM and IgG tests are conducted to detect IgM and IgG antibodies. ${ }^{4,5}$ The method commonly used in those examinations is immunochromatography. Nevertheless, although the serological test is useful for the detection of DVI from day 2-3 to 7 after the fever, it is difficult to detect specifically at the onset of fever ( $\leq$ five days). ${ }^{6}$ 
Consequently, Polymerase Chain Reaction (PCR) test is also carried out to detect dengue virus infection. ${ }^{6}$ Polymerase chain reaction is a gold standard test to detect dengue virus serotype, also considered as a diagnostic parameter an epidemiologic study within the first five days of fever. ${ }^{7,8,11}$ Polymerase chain reaction with biomolecular method even is considered as a more sensitive, specific, faster and better method to detect dengue virus than viral culture method. ${ }^{7,9,11}$ In general, PCR as a dengue screening method consists of two types, namely conventional PCR Dengue and Real-time RT-PCR Dengue assays. ${ }^{10}$ Compared to conventional PCR Dengue, Real-time PCR Dengue is not only more sensitive, accurate and objective, but also capable of detecting various dengue virus serotypes. ${ }^{11-13}$

As a result, this research aimed to examine the correlation of dengue virus serotypes and DVI severity in adults using Real-time RT-PCR dengue assay. ${ }^{12-14}$ Results of this research then are expected to be used as a reference for determining diagnosis and therapy of DVI. ${ }^{15}$

\section{METHODS}

This research was an observational analytical study with a cross-sectional design. This research was conducted from February to July 2016. Screening of NS1, anti-dengue IgM and anti-dengue IgG was performed with the immunochromatographic rapid test. ${ }^{13}$ The screening was conducted at Clinical Pathology Laboratory of the Dr.Soetomo Hospital in Surabaya. Meanwhile, Dengue virus RNA was examined with Real-time PCR Dengue assay at Dengue Laboratory of Eijkman Institute for Molecular Biology in Jakarta.

Moreover, subjects of this research were DVI patients treated at the Emergency Unit and Tropical Infection Division of the Internal Medicine Department, Dr. Soetomo Hospital, Surabaya. Those subjects were selected since they were patients aged over 14 years and diagnosed with DVI by an internist due to clinical and laboratory examinations' results as determined by WHO (2011) without other accompanying diseases, such as autoimmune and HIV/AIDS. Those patients also had signed the informed consent for participating in this research.

Next, venous blood samples were taken from the cubital vein in sterile and lege artist condition as much as 10 milliliters and then put into vacutainer tubes without anticoagulants. Afterward, those tubes were labeled (name of patient and date of sampling). Those samples then were centrifugated at a rate of
$3,000 \mathrm{rpm}$ for 5 minutes to obtain serum, and stored at $-80^{\circ} \mathrm{C}$ until examined.then were centrifugated at a rate of 3,000 rpm for 5 minutes to obtain serum and stored at $-80^{\circ} \mathrm{C}$ until examined.

\section{RESULTS AND DISCUSSIONS}

The study was conducted from February to July 2016. The number of samples selected was 100 subjects. After those samples had positive screening results, Real-time RT-PCR Dengue test was conducted for detecting dengue virus serotypes.

Table 1. Results of the RT-PCR dengue test and the characteristics of subjects

\begin{tabular}{lcc}
\hline RT-PCR dengue assay & $\begin{array}{c}\text { Total } \\
\text { (n= 100) }\end{array}$ & $\begin{array}{c}\text { Percentage } \\
\text { (\%) }\end{array}$ \\
\hline Positive & 46 & 46 \\
Negative & 54 & 54 \\
Total & 100 & 100 \\
\hline Characteristic of samples & $\begin{array}{c}\text { Total } \\
\text { (n=46) }\end{array}$ & $\begin{array}{c}\text { Percentage } \\
\text { (n=\%) }\end{array}$ \\
Sex & & \\
Male & 27 & 58.7 \\
Female & 19 & 41.7 \\
Total & 46 & 100 \\
Day of fever & & \\
3 & 10 & 21.7 \\
4 & 16 & 34.8 \\
5 & 10 & 21.7 \\
6 & 5 & 10.9 \\
7 & 5 & 10.9 \\
Total & 46 & 100 \\
Dengue virus serotypes & & \\
DENV-1 & 8 & 17.4 \\
DENV-2 & 8 & 17.4 \\
DENV-3 & 29 & 63.0 \\
Mixed DENV-1 and & 1 & 2.2 \\
DENV-3 & 0 & 0 \\
DENV-4 & 46 & 100 \\
Total & &
\end{tabular}

Total

The degree of DVI severity DF

DVI type I

DVI type II

DVI type III

DVI type IV

Total

Hematology leukocytes

$\begin{array}{lll}\text { Decreasing } & 15 & 32.6\end{array}$

Normal

$31 \quad 67.4$

Increasing

Total

$0 \quad 0$

$46 \quad 100$

Platelets $\leq 100 \quad 39 \quad 84.9$

$\begin{array}{lll}>100 & 1 & 2.2\end{array}$

Total $46 \quad 100$ 
Results of the Real-time RT-PCR Dengue test showed that there were $46(46 \%)$ subjects with positive dengue virus as seen in Table 1.

Those forty-six subjects consisted of 27 (58.7\%) males and 19 (41.7\%) females aged between 14-61 years-old with an average age of 24-25 years. Those DVI subjects went to the hospital on day 3 to

Table 3. The frequency of thrombocyte percentage towards DVI severity degree

\begin{tabular}{lcccccc}
\hline $\begin{array}{c}\text { Thrombocyte } \\
\text { percentage }\end{array}$ & DF & $\begin{array}{c}\text { DVI } \\
\text { type I }\end{array}$ & $\begin{array}{c}\text { DVI severity degree } \\
\text { type II }\end{array}$ & $\begin{array}{c}\text { DVI } \\
\text { type III }\end{array}$ & DVI type IV & $\begin{array}{c}\text { Total } \\
n \\
(\%)\end{array}$ \\
\hline & 2 & 22 & 12 & 3 & $0(0)$ & 39 \\
& $(5.1)$ & $(56.4)$ & $(30.8)$ & $(7.7)$ & & $(100)$ \\
$101-150$ & 3 & 2 & 2 & 0 & $0(0)$ & 7 \\
& $(42.9)$ & $(28.6)$ & $(28.6)$ & $(0)$ & & $(100)$ \\
Total & $5(10.9)$ & 24 & 14 & 3 & $0(0)$ & 46 \\
& & $(52.2)$ & $(30.4)$ & $(6.5)$ & & $(100)$ \\
\hline
\end{tabular}

7 after the fever. The $4^{\text {th }}$ day sampling indicated the highest positivity $(34.8 \%)$ followed with the $3^{\text {rd }}$ day, the $5^{\text {th }}$ day, the $6^{\text {th }}$ day and the $7^{\text {th }}$ day of sampling. In other words, the positivity of the Real-time RTPCR Dengue test' results decreased after day 5 Thus, many patients mostly come on day 3 to 5 .

After those one-hundred samples suspected

and DF 5 subjects (10.5\%). None of the research subjects suffered from DVI type IV and DSS.

Plasma leakage is a sign of pathognomonic DVI detected by hematocrit, albumin, pleural effusion and ascites as its parameters. Besides, it is also indicated with other organ abnormalities as well as unusual expanded dengue syndrome or isolated organopathy manifestations that can be

identified with pleural effusions and ascites. ${ }^{2,4,15}$ The parameters are usually also used to distinguish DF from DVI. ${ }^{2,15}$ In this research, an increase in the amount of hematocrit and a decrease in the amount of albumin were used as parameters.

Moreover, the laboratory results showed that fifteen research subjects (32.6\%) had decreased leuko

Table 4. The frequency of hematocrit percentage towards dengue virus serotypes

\begin{tabular}{|c|c|c|c|c|c|c|}
\hline \multirow[b]{2}{*}{ Hematocrit percentage } & \multicolumn{5}{|c|}{ Dengue virus serotypes } & \multirow[b]{2}{*}{ Total n (\%) } \\
\hline & $\begin{array}{c}\text { DENV-1 } \\
\text { n (\%) }\end{array}$ & DENV-2 n (\%) & $\begin{array}{c}\text { DENV-3 n } \\
(\%)\end{array}$ & $\begin{array}{c}\text { Mixed } \\
\text { DENV-1 and } \\
\text { DENV-3 } \\
\mathrm{n}(\%)\end{array}$ & $\begin{array}{c}\text { DENV-4 } \\
\text { n (\%) }\end{array}$ & \\
\hline${ }^{3} 20 \%$ & $1(16.7)$ & $1(16.7)$ & $4(66.6)$ & $0(0)$ & $0(0)$ & $6(100)$ \\
\hline$<20 \%$ & $6(16.2)$ & $8(21.6)$ & $22(59.5)$ & $1(2.7)$ & $0(0)$ & $37(100)$ \\
\hline No data available & - & - & - & - & - & $3(100)$ \\
\hline Total & 7 (16.3) & $9(20.9)$ & $26(60.5)$ & $1(2.3)$ & $00)$ & $43(100)$ \\
\hline
\end{tabular}

with DVI showed positive screening results, they were examined with Real-time RT-PCR Dengue assay. Results of the Real-time RT-PCR Dengue assay showed that there were $46(46 \%)$ subjects with positive dengue virus as seen in Table 2.

In Table 1, the dengue virus serotype of the research subjects was dominated by DENV-3, followed by DENV-2, DENV-1 and mixed DENV-1 and DENV-3. DENV-4 was not found in the dengue virus serotype of the research subjects.

In addition, the degree of DVI severity in the research subjects was dominated by DVI type I as many as 22 subjects ( $47.8 \%)$, followed by DVI type II 14 subjects (30.4\%), DVI type III 5 subjects (10.5\%), was $1,700 / \mathrm{mm}^{3}$ found in DVI type II with DENV-2. cytes/leukopenia, while thirty-one research subjects (67.4\%) had normal leukocytes. In other words, none of the research subjects had increased leukocytes/ leukocytosis. The lowest leukocyte count Table 3, besides, thrombocytopenia was known to be mostly found in DVI type I (56.4\%), followed with DVI type II (30.8\%), DVI type III (7.7\%) and DF (5.1\%). Thrombocytopenia was not found in DVI type I.

Also, forty-three research subjects had hematocrit examination result data, while three research subjects did not have any result data. The increased hematocrit count $(\geq 20 \%)$ is considered as a sign of the most prominent hemoconcentration. In Table 5, there were six research subjects who had plasma leakage, three of them (50\%) with DVI type I, two of them 
(33.3\%) with DVI type II and another (16.7\%) with DVI type III. Plasma leakage, however, ware not found in DVI type IV and DF since none of the research subjects suffered from DVI type IV and DF.

Plasma leakage is difficult to detect if the patient is admitted to hospital and treated with fluidtherapy due to unobserved laboratory examination results. Thus, albumin is used as a parameter to determine plasma leakage. A decrease in albumin level as much as $>0.5 \mathrm{~g} / \mathrm{dL}$ from baseline or $<3.5 \mathrm{~g} \%$ is considered as an indirect indicator of plasma leakage.

In this research, there were twenty-six research subjects without albumin examination result data, while the other twenty research subjects had data. In Table 6, six of those twenty subjects (43.7\%) had decreased albumin level. The decreased albumin level was not found in the subjects with DENV-1, mixed DENV-1 and DENV-3 and DENV-4. It is difficult to determine plasma leakage by using this parameter since not all subjects had checked

In Table 7, the decreased albumin level was found in four research subjects with DVI type I, two research subjects with DVI type II and one research subject with DF. The decreased albumin level ware not found in DVI type III and DVI type IV. There were plasma leakage signs, such as pleural effusion, ascites and edema on the gallbladder wall. Chest X-Ray photo (with Right Lateral Decubitus = RLD position) and abdominal ultrasonography, thus, is usually used to detect plasma leakage. Nevertheless, there was no data from such examinations in this research.

Next, Fischer's exact test was performed to analyze the correlation of dengue virus serotypes and DVI severity degree. Results of the statistical test revealed that there was no correlation between dengue virus serotypes and DVI severity degree with a $p$-value of 0.510 . The dominance of dengue virus severity was DVI type I (22 cases), followed with DVI type I1 (14 cases), DF (5 cases) and DVI type III (5 cases). Undifferentiated fever, DVI type IV and expanded dengue syndrome were not found in this research.

\section{CONCLUSION AND SUGGESTION}

Finally, it can be concluded that the dengue virus serotype of the research subjects was dominated by DENV-3, followed by DENV-2, DENV-1 and mixed DENV-1 and DENV-3. DENV-4 was not found in the dengue virus serotype of the research subjects. Meanwhile, the degree of DVI severity in the research subjects was dominated by DVI type I, followed by DVI type II, DVI type III and DF.

Table 5. The frequency of hematocrit percentage towards DVI severity degree

DVI severity degree

\begin{tabular}{lcccccc}
$\begin{array}{c}\text { Hematocrit per- } \\
\text { centage }\end{array}$ & $\begin{array}{c}\text { DF } \\
(\mathrm{n} \%)\end{array}$ & $\begin{array}{c}\text { DVI type I } \\
(\mathrm{n} \%)\end{array}$ & $\begin{array}{c}\text { DVI type II } \\
(\mathrm{n} \%)\end{array}$ & $\begin{array}{c}\text { DVI type III } \\
(\mathrm{n} \%)\end{array}$ & $\begin{array}{c}\text { DVI type IV } \\
(\mathrm{n} \%)\end{array}$ & $\begin{array}{c}\text { Total } \\
(\mathrm{n} \%)\end{array}$ \\
\hline${ }^{3} 20 \%$ & $0(0)$ & $3(50)$ & $2(33.3)$ & $1(16.7)$ & $0(0)$ & $6(100)$ \\
$<20 \%$ & $616.2)$ & $16(43.2)$ & $1027.1)$ & $513.5)$ & $0(0)$ & $37(100)$ \\
No data available & - & - & - & - & - & $3(100)$ \\
$\quad$ Total & $6(14)$ & $19(44.1)$ & $12(27.9)$ & $6(14)$ & $0(0)$ & $43(100)$ \\
\hline
\end{tabular}

Table 6. The frequency of albumin percentage towards dengue virus serotypes

\begin{tabular}{|c|c|c|c|c|c|c|}
\hline \multirow[b]{2}{*}{ Albumin } & \multicolumn{5}{|c|}{ Dengue virus serotypes } & \multirow[b]{2}{*}{$\begin{array}{l}\text { Total } \\
\mathrm{n}(\%)\end{array}$} \\
\hline & $\begin{array}{c}\text { DENV-1 } \\
\mathrm{n}(\%)\end{array}$ & DENV-2 n (\%) & $\begin{array}{c}\text { DENV-3 n } \\
(\%)\end{array}$ & $\begin{array}{c}\text { Mixed } \\
\text { DENV-1 and DENV-3 } \\
\mathrm{n}(\%) \\
\end{array}$ & $\begin{array}{c}\text { DENV-4 } \\
\mathrm{n}(\%)\end{array}$ & \\
\hline$<3.5$ & $0(0)$ & $3(6.5)$ & $3(6.5)$ & $0(0)$ & 0 & $6(15.2)$ \\
\hline $3.5-5.0$ & $2(4.4)$ & $0(0)$ & 10(21.7) & $1(2.2)$ & 0 & $13(28.3)$ \\
\hline No data available & - & - & - & - & - & $26(56.5)$ \\
\hline Total & 2(4.4) & $3(6.5)$ & $13(28.3)$ & $1(2.2)$ & 0 & $46(100)$ \\
\hline
\end{tabular}


Table 7. The frequency of albumin percentage towards DVI severity degree

\begin{tabular}{lcccccc}
\hline & \multicolumn{3}{c}{ DVI severity degree } & & Total \\
Albumin (g/\%) & \begin{tabular}{c} 
DF \\
\cline { 2 - 5 }
\end{tabular} & $\begin{array}{c}\text { DVI type I } \\
(\mathrm{n} \%)\end{array}$ & $\begin{array}{c}\text { DVI type II (n } \\
\%)\end{array}$ & $\begin{array}{c}\text { DVI type III } \\
(\mathrm{n} \%)\end{array}$ & $\begin{array}{c}\text { DVI type IV } \\
(\mathrm{n} \%)\end{array}$ & $\begin{array}{c}\mathrm{n}(\%) \\
7(100)\end{array}$ \\
\hline$<3.5$ & $1(14.3)$ & $4(57.1)$ & $2(28.6)$ & $0(0)$ & $0(0)$ & $13(100)$ \\
$3.5-5.0$ & $1(7.7)$ & $8(61.5)$ & $2(15.4)$ & $2(15.4)$ & $0(0)$ & $26(100)$ \\
No data available & - & - & - & - & - & $46(100)$ \\
Total & $2(4.3)$ & $12(21.7)$ & $4(8.7)$ & $2(4.3)$ & $0(0)$ & \\
\hline
\end{tabular}

None of the research subjects suffered from DVI type IV and DSS. Also, there was no correlation between dengue virus serotypes and DVI severity degree in patients. PCR test, as a result, is recommended for detecting dengue virus infection early to prevent its severity. Nevertheless, further researches are still needed to determine dengue virus serotypes in Indonesia.

\section{REFFERENCES}

1. Kementerian Kesehatan Republik Indonesia. Data peningkatan kasus demam berdarah dengue di Jawa Timur. http:www.kemkes.go id. 2014. Diunduh tanggal 27 Desember 2015.

2. WHO. Comprehensive guidelines for prevention and control of dengue and dengue hemorrhagic fever, World Health Organization Regional Office for SouthEast Asia, New Delhi, 2011. http://www.searo.who.int diunduh tanggal 7 Desember 2016.

3. Sekaran SD, Ew CL, Subramaniam G, Kanthesh BM. Sensitivity of dengue virus NS-1 detection in primary and secondary infections. Journal of Clinical Microbiology, 2009; 3(3):105-110.

4. Andriyoko B, Parwati I, Tjandrwati A, Lismayanti L. Penentuan serotipe virus dengue dan gambaran manifestasi klinis serta hematologi rutin pada infeksi virus dengue, Majalah Kedokteran Bandung, 2012; 44(4): 253-260.

5. Candra A. Dengue Hemorrhagic Fever: Epidemiology, Pathogenesis and Its Transmission Risk Factors. Aspirator 2010; 2(2): $110-119$.

6. Gurugama R, Garg P, Perera J, Wijewickrama A, Seneviratne SL. Dengue viral infections. Indian Journal Dermatol, 2010; 55(1): 68-78.

7. Sasmono RT, Aryati A, Wardhani P. Performance of Simplexa dengue molecular assay compared to conventional and SYBR green RT-PCR for detection of dengue infection in Indonesia. Plos One, 2014; 9(8): 19.

8. Aryati, Wardhani P, Yohan B, Aksono E B, Sasmono R $\mathrm{J}$,et al. Dengue serotypes distribution in Surabaya in the year 2012, Indonesian Journal of Clinical Pathology and Medical Laboratory, 2012; 19(1): 2--3.
9. Tjahjono G, Nasronudin. Imunopatogenesis demam berdarah dengue. Dalam: Nasronudin, Hadi U, Vitanata M. Penyakit infeksi di Indonesia solusi kini dan mendatang. Ed ke-2., Surabaya, Airlangga University Press, 2011; 117-121.

10. Lai YL, Chung YK, Tan HC, Yap HF, Yap G, Ooi EE, Ng LC. Cost-effective real-time reverse transcriptase PCR (RT$P C R$ ) to screen for dengue virus followed by rapid single -tube multiplex RT-PCR for serotyping of the virus. Journal of Clinical Microbiology. 2007; 45(1): 935-941.

11. Yuwono T. Teori, dan Aplikasi Polymerase Chain Reasction. Panduan eksperimen PCR untuk memecahkan masalah biologi terkini. Ed ke-1., Yogyakarta andi Yogyakarta press, 2006; 1-16.

12. Roche. Magna Pure LC Total Nuclei Acid Isolation Kit version 2015: 16, Cat No. 03038505001 . lifescience.roche.com

13. Nasronudin. Mekanisme perdarahan pada infeksi virus dengue. Dalam: Nasronudin, Hadi U, Vitanata M. Penyakit Infeksi di Indonesia Solusi Kini dan Mendatang, Ed ke-2., Surabaya, Airlangga University Press, 2011; 112116.

14. Simplexa ${ }^{\mathrm{TM}}$ Dengue Focus Diagnostics REF MOL3100, 2012. Usman Hadi. Tata Laksana terhadap Tersangka/ Kasus DBD/SSD pada Orang dewasa. Editor: Nasronudin, Vitanata, Erwin AT, Bramantono, Suharto, Eddy Soewandojo. Dalam: Penyakit Infeksi di Indonesia. Surabaya, Airlangga University Press. 2007; 69-72Seema, Jain SK, 2005.

16. Molecular mechanism of pathogenesis of dengue virus : entry and fusion with target cell. J Clin Bio 20: 92-103..

17. Shu PY, Chen S, Chang Y, Yueh L, Chow L, Chien L, et al, 2000. Dengue NS1

18. response: isotype distribution and serotyping in patients with dengue

19. fever and dengue hemorrhagic fever. J Med Virol, 62; 224-32.

20. Shu PY, Huang JH, 2004. Current advances in dengue diagnosis. Clin Diagn Lab Immunol, 11:642-50

21. Soegijanto S, 1999. Masalah penyakit DBD di Indonesia. Dalam: Soegijanto S. Demam berdarah dengue.

22. Surabaya: Airlangga University Press, hal 5-9. 
23. Soegijanto S, 2006. Bahaya yang mengintai endemisitas DBD di Indonesia.Dalam: Soegijanto $\mathrm{S}$. Demam berdarah dengue. Edisi ke-2. Surabaya: Airlangga University Press, hal 25-44.

24. Soegijanto S, 2006. Aspek imunologi penyakit demam berdarah dengue. Dalam:

25. Soegijanto S. Demam berdarah dengue. Edisi ke-2. 28. Surabaya: Airlangga

26. University Press, hal 45-79.

27. Soegijanto S, 2006. Patogenesis dan Perubahan Patofisiologi pada infeksi virusdengue. Dalam: Soegijanto S. Demam berdarah dengue. Edisi ke-2. Surabaya: Airlangga University Press, hal 61-84.
27. Tjiptaningsih, 2000. Gambaran jumlah leukosit dan hitung jenisnya padapenderita demam berdarah dengue, upaya menentukan parameter dinirenjatan. Karya Akhir Program Pendidikan Spesialis I. Lab/ SMF IlmuKesehatan Anak FK Unair/ RSUD Dr. Soetomo Surabaya.

Tri Aji B, 2000. Hubungan Titer IgM, IgG, Rasio IgM/IgG dengan derajat klinis demam berdarah dengue. Karya Akhir Program Pendidikan Spesialis I. Lab/ SMF IImu Kesehatan Anak FK Unair/ RSUD Dr. Soetomo Surabaya. 